\title{
Suspended sediment yield and climate change in Kamchatka, Far East of Russia
}

\author{
Ludmila V. Kuksina \\ Laboratory of soil erosion and channel processes, Faculty of geography, \\ Moscow State University, Moscow, 119991, Russia \\ Correspondence: Ludmila V. Kuksina (ludmilakuksina@gmail.com) \\ Published: 1 August 2019
}

\begin{abstract}
Key factors of sediment yield formation and variability in the Kamchatsky Krai are relief characteristics and climate (especially precipitation). The last research in climate change in Kamchatka demonstrates climate warming - mean annual air temperature has increased on $1.5^{\circ} \mathrm{C}$ during the period from 1951 to 2009 in average (the maximum increase was revealed in the west of Kamchatka and in the Kamchatka River valley, the minimum one - in the extreme south and north). Decrease of annual precipitation was observed at the same period. In addition frequency and intensity of precipitation is growing. Thereby described climate changes in Kamchatka influence on sediment yield characteristics directly (influence of precipitation on surface washout formation) and indirectly (through water runoff and hydrological regime of rivers changes). Analysis of spatiotemporal variability in suspended sediment yield demonstrated decrease since late 1970-early 1980 in the most part of rivers in the Kamchatsky Krai. Revealed fluctuations demonstrate very good coincidence with precipitation amount variability. Decrease of precipitation leads to corresponding diminution of rainfall erosive factor in the territory which is the key factor of suspended sediment yield formation and variability in rivers in the Kamchatsky Krai. The value of reduction varies from $1 \%$ to $45 \%$ and involves decrease of erosion rates in the territory. Thereby climate change influences on suspended sediment yield in multiple-valued way. Income of friable volcanic deposits on the catchment surface is the key factor of suspended sediment yield formation and variability in some river basins under the impact of volcanic eruptions, and in combination with raising precipitation it can lead to catastrophic increase of sediment yield.
\end{abstract}

\section{Introduction}

The current climate change occurs all over the World and leads to increase of air temperature, amount, intensity and frequency of precipitation, and rainfall erosive factor, and as a consequence to growth of severe floods and erosive events (landslides, mudflows (including lahars)) causing the increase of sediment yield, basin component of sediment yield, and channel transformations. According to the last Report on climatic risks in the Russian Federation (Report on climate risk, 2017) climate changes are faster in Russia in comparison to the Earth, and severity of hydrological events and their damage growths correspondingly. Increase of high precipitation frequency (Groisman et al., 2005) and warming climate (Huntington, 2006) leads to the growth of power and frequency of floods, relief reformation and high sedi- ment yields (Kuksina et al., 2017; Mueller, Pfister, 2011), and these extreme hydrometeorological events rank the first position among global risks threatening humanity (Report on climate risk, 2017).

The Kamchatsky Krai could be very vulnerable to climate change due to natural features of the territory including vast distribution of friable volcanic deposits which are very easyportable by water (Kraevaya, 1969), and specific exposed landscapes (repetitive catastrophic landslides in Geyser Valley in 2007, 2014, and 2017 due to unstable rocks on its flanks, Leonov et al., 2014). Volcanic activity is specific feature of sediment yield formation and spatio-temporal distribution in Kamchatka (Kuksina and Alexeevsky, 2017). Volcanic eruptions are the first-rate source of sediments in planetary scale. Among the whole natural phenomena lead- 
ing to extreme increase of sediment yield (volcanic eruptions, earthquakes, heavy rains, and dam failure), volcanoes are the absolute leaders (Korup, 2012). Highly erodible volcanogenic deposits fall in the river basins during volcanic eruptions due to ashfalls, pyroclastic flows, and lahars (Carrivick et al., 2010; Gran and Montgomery, 2005; Lavigne and Thouret, 2002; Major, 2004).

Volcanic eruptions lead to extreme increasing of suspended sediment yield in rivers draining flanks of volcanoes. Annual suspended sediment yield exceeded background level in 500 times after the catastrophic eruption of Mount St Helens in 1980. Volcanic eruptions impact on hydrological regime of rivers. Within 5-10 years after the catastrophic eruption of Mount St Helens on the 18 May 1980 increasing of peak discharges was observed in autumn and winter due to decrease of lag-time and increase of channel efficiency (Major and Mark, 2006). In some cases the processes of water transfer changes in comparison with the period before eruption. In the post eruption period loss of canopy interception, the greater amount of precipitation reaching the ground surface, reduced evapotranspiration, the reduction of surface infiltration and more prominent overland flow were observed (Major et al., 2009). Thereby volcanic activity could be the separate reason of water runoff and sediment yield fluctuations in Kamchatka rivers, and it can influence on river runoff characteristics through increasing precipitation. Combination of such events as high precipitation, increase of air temperature and intensification of snow and ice melt, and volcanic eruptions could lead to catastrophic natural events and great increase of sediment yield (lahars, lake burst, etc.) (Korup, 2012). Most part of the rivers in Kamchatka is spawning area for valuable salmon species (such as king salmon, red salmon, silver salmon, etc.), and for some of them catch of fish exceeds $90 \%$ of the total amount in the Russian Far East. River ecosystems and spawning areas depend on hydrological conditions including suspended sediment concentration.

The last research in climate change in Kamchatka (Shkaberda and Vasilevskaya, 2014) demonstrates climate warming - mean annual air temperature has increased on $1.5^{\circ} \mathrm{C}$ during the period from 1951 to 2009 in average (the maximum increase was revealed in the west of Kamchatka and in the Kamchatka River valley, the minimum one - in the extreme south and north); "continentality" of climate decrease on $6 \%-16 \%$ in some regions of the peninsula. Variability of annual precipitation was multiple-valued at the same period. Decrease of precipitation was observed at the same period almost everywhere in the Kamchatsky Krai. In addition frequency and intensity of precipitation is growing (Groisman et al., 2005). Climate change leads to correspondence variations in water runoff and sediment yield in Kamchatka.

Key factors of sediment yield formation and variability in the Kamchatsky Krai are relief characteristics and precipitation (Kuksina and Alexeevsky, 2018). Thereby described climate changes in Kamchatka influence on sediment yield characteristics directly (influence of precipitation on surface washout formation) and indirectly (through water runoff and hydrological regime of rivers changes). Thereby climate change influences on suspended sediment yield in multiplevalued way. Income of friable volcanic deposits on the catchment surface is the key factor of suspended sediment yield formation and variability in some river basins under the impact of volcanic eruptions.

The main goal of this paper is analysis of the features of spatial and temporal variability of suspended sediment yield in the state-of-the-art (current) hydroclimatic conditions.

\section{Materials and methods}

This study is based on stationary monitoring data on air temperature, precipitation, water runoff and suspended sediment yield characteristics. The data on air temperature and precipitation contains information for 21 stations (Fig. 1), and duration of observations varies from 80 (Oktyabrskaya) to 174 years (Petropavlovsk-Kamchatsky) for air temperature, and from 16 to 51 for precipitation.

There were 269 monitoring stations that measured water runoff and levels in the territory of the Kamchatsky Krai for the period of hydrometeorological observations (since 1930). 86 gauges operated in 2010. The average duration of the observations is 22 years. The majority of the water runoff gauges are situated in river basins with areas less than $2000 \mathrm{~km}^{2}$ (76\% of all gauges). The gauges are distributed very unevenly. There are a relatively large number of gauges in the large plain rivers (the Avacha River (12), the Kamchatka River (28)) that flow into the Pacific Ocean. There are only 8 operating gauges in the continental part of the Kamchatsky Krai now (6 of them are situated in the Penzhina River basin; 10 gauges are closed).

Regular monitoring of suspended sediment yield characteristics in rivers of the Kamchatsky Krai was started in 1940 in the Kamchatka River (gauge Kliuchi) and the Avacha River (gauge Elizovo). Between 1941-2015, suspended sediment yield monitoring was implemented in 69 stations. 6 of them had only episodic data, and they were excluded from this study's analysis. The duration of observations vary from 6 to 74 years for 63 selected gauges (see Fig. 1). More than half of the gauges $(54 \%)$ were situated in river basins with catchment areas greater than $500 \mathrm{~km}^{2}$; hence, $46 \%$ were in river basins with areas less than $500 \mathrm{~km}^{2} .20$ stations with observations on suspended sediment yield currently operate in the territory. The duration of observations of these gauges varies from 37 to 74 years.

The representativeness (Helsel and Hirsch, 2002) of all of the series of observations was evaluated, and even measurement periods as short as 6 to 10 years appear to be representative (probably the observation data hit into the water- and sediment-average period with absence of significant hydrological events). As a result, these data were used for defining 


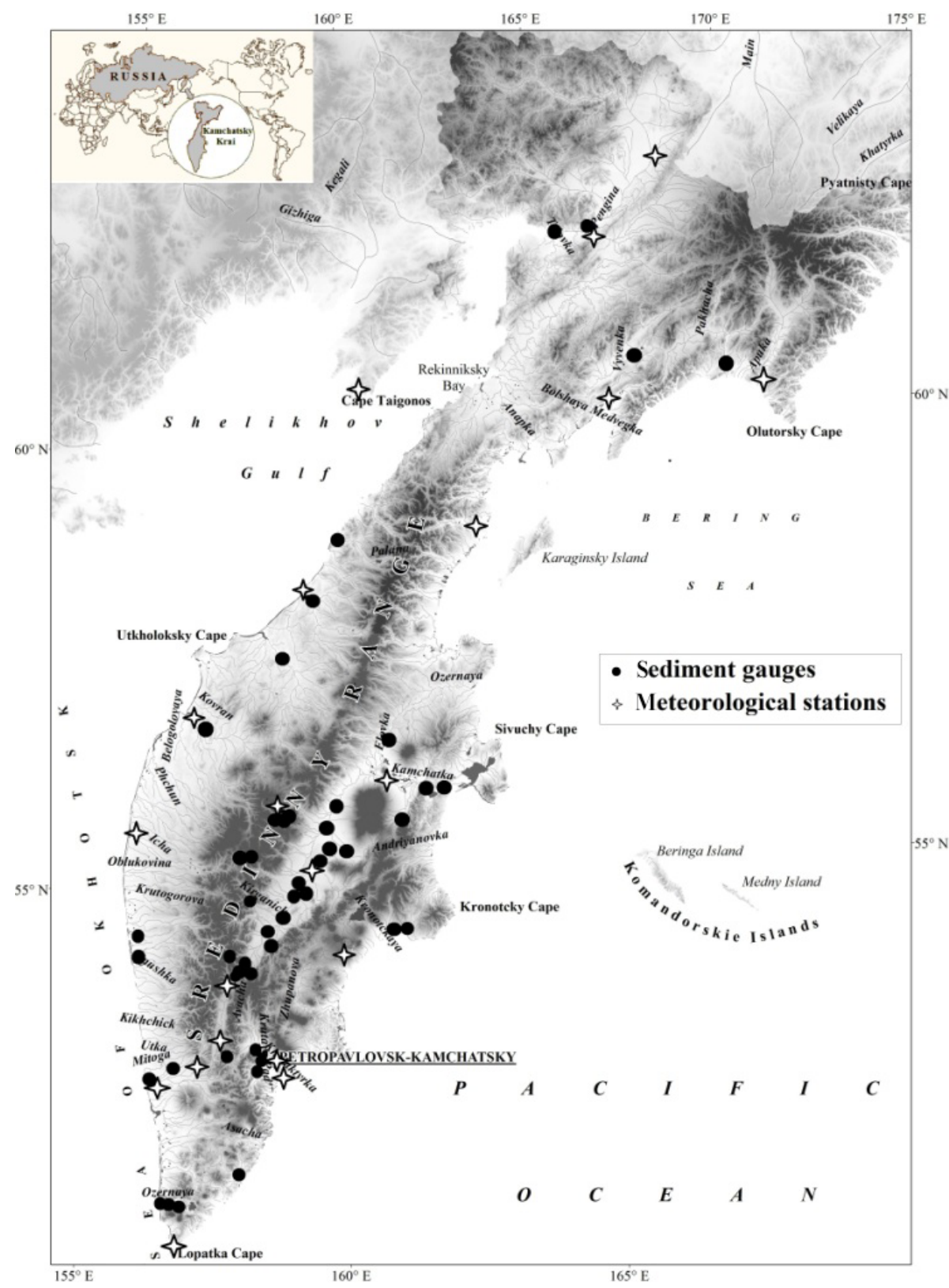

Figure 1. Distribution of suspended sediment yield and meteorological monitoring stations in the Kamchatsky Krai. Rivers: (1) Paren', (2) Pakhacha, (3) Penzhina, (4) Avacha, (5) Talovka, (6) Tigil', (7) Udova, (8) Asacha, (9) Bol'shaya Vorovskaya, (10) Bol'shaya (Bystraya), (11) Bryumka, (12) Phchyn, (13) Voyampolka, (14) Vyvenka, (15) Zhupanova, (16) Icha, (17) Kamchatka, (18) Kronotckaya, (19) Oblukovina, (20) Ozernaya, (21) Ozernaya, (22) Palana, (23) Khairyuzova.

water regime types and zones having similar suspended sediment yield characteristics.

The long-term trends of water runoff, suspended sediment yield, precipitation and air temperature variability were determined using a difference-integral curves analysis (Evstignnev, 1990; Manh et al., 2013).

\section{Climate change in Kamchatka}

The last research in climate change in Kamchatka (Shkaberda, 2014) demonstrates climate warming - mean annual air temperature has increased on $1.5^{\circ} \mathrm{C}$ during the period from 1951 to 2009 in average (the maximum increase was revealed in the west of Kamchatka and in the Kamchatka River valley, the minimum one - in the extreme south and north); "continentality" of climate decrease on $6 \%-16 \%$ in 

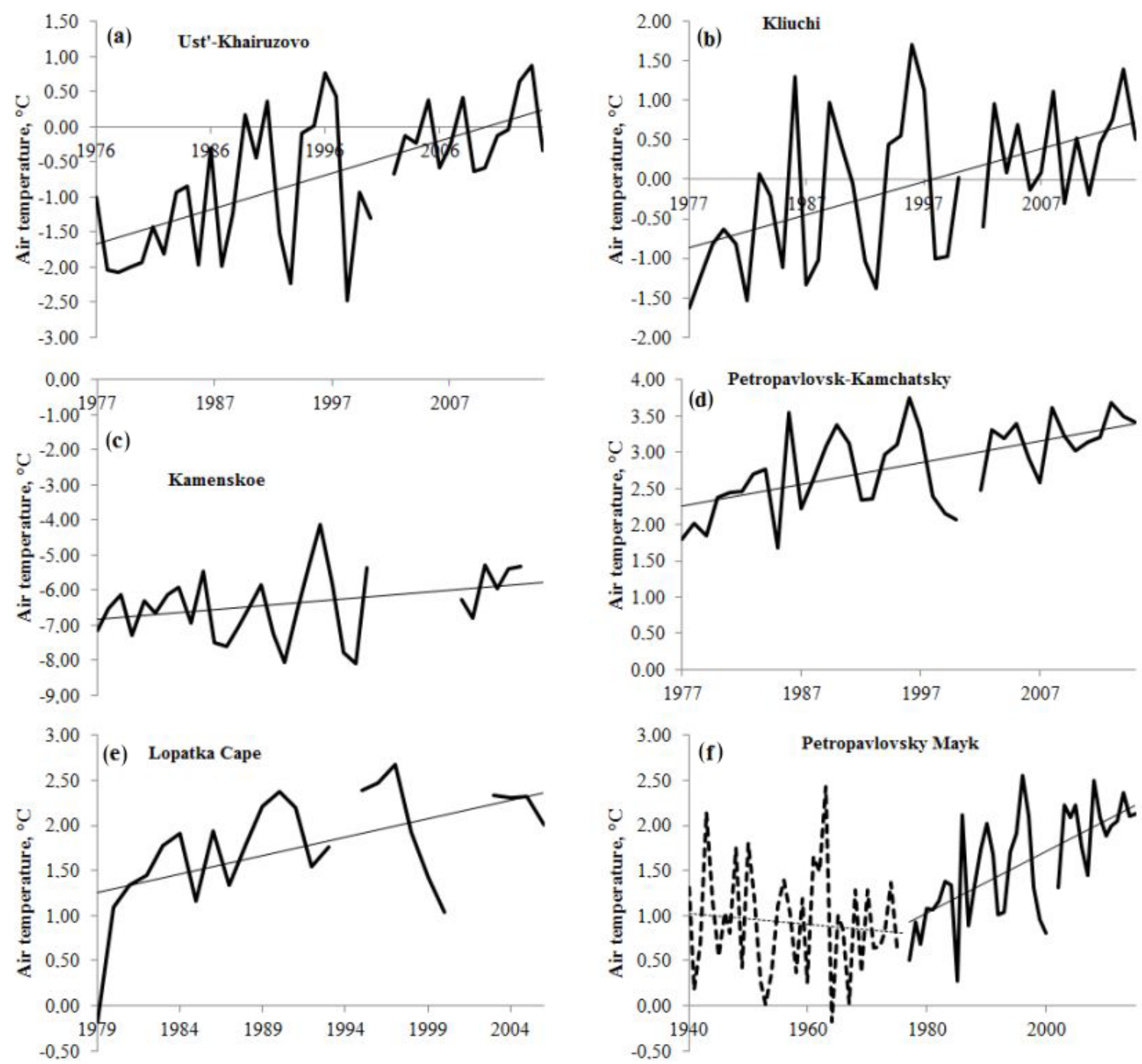

Figure 2. Trends in air temperature change in the western coast (Ust'-Khairuzovo station, a), central part (Kliuchu station , b), northern (continental) part (Kamenskoe station, c), eastern coast (Petropavlovsk-Kamchatsky station, d), Petropavlovky Mayk station, (f), and the very south of the peninsula (Lopatka Cape station, e), in the Kamchatsky Krai.

some regions of the peninsula. Variability of annual precipitation was multiple-valued at the same period. Decrease of precipitation was observed in the north, western and northeastern coast, and in the Kamchatka River valley. Increase of them was observed in the eastern coast and in mountainous regions.

Analysis of climate change in Kamchatka was implemented on the basis of annual air temperature and total annual precipitation fluctuations in 21 stations in the Kamchatsky Krai.

Analysis of all temperature ranges revealed intensive increase of that characteristic all over the Kamchatsky Krai. The mean annual air temperature has increased on $1.5^{\circ} \mathrm{C}$ during the period from 1951 to 2009 in average (Shkaberda, 2014). The maximum increase was revealed in the western coast of the peninsula. In Ust'-Khairuzovo station the air temperature increased on $1.9^{\circ} \mathrm{C}$ for the period from late 1970 to 2015 (Fig. 2a). Intensive growth in air temperature is also observed in the Kamchatka River valley. According to the Dolinovka and the Kluichi stations the temperature increased on $1.6^{\circ} \mathrm{C}$ for the period from late 1970 to 2015 (Fig. 2b). Less increase of air temperature is registered in the north continental regions (not more than $1.0^{\circ} \mathrm{C}$ ), in the eastern coast of the peninsula $\left(1.1^{\circ} \mathrm{C}\right)$ and in the very south of the peninsula (Lopatka Cape, not more than $1.1^{\circ} \mathrm{C}$ ) (Fig. 2c, d, e).

The most intensive growth of air temperature has been observed since late 1970, and in some stations the tendency even changed to the opposite one. For example, air temperature decreased till the late 1970 in Kamenskoe, Petropavlovsky Mayak, Lopatka Cape and other stations, and then it started to increase rapidly (Fig. 2f). 

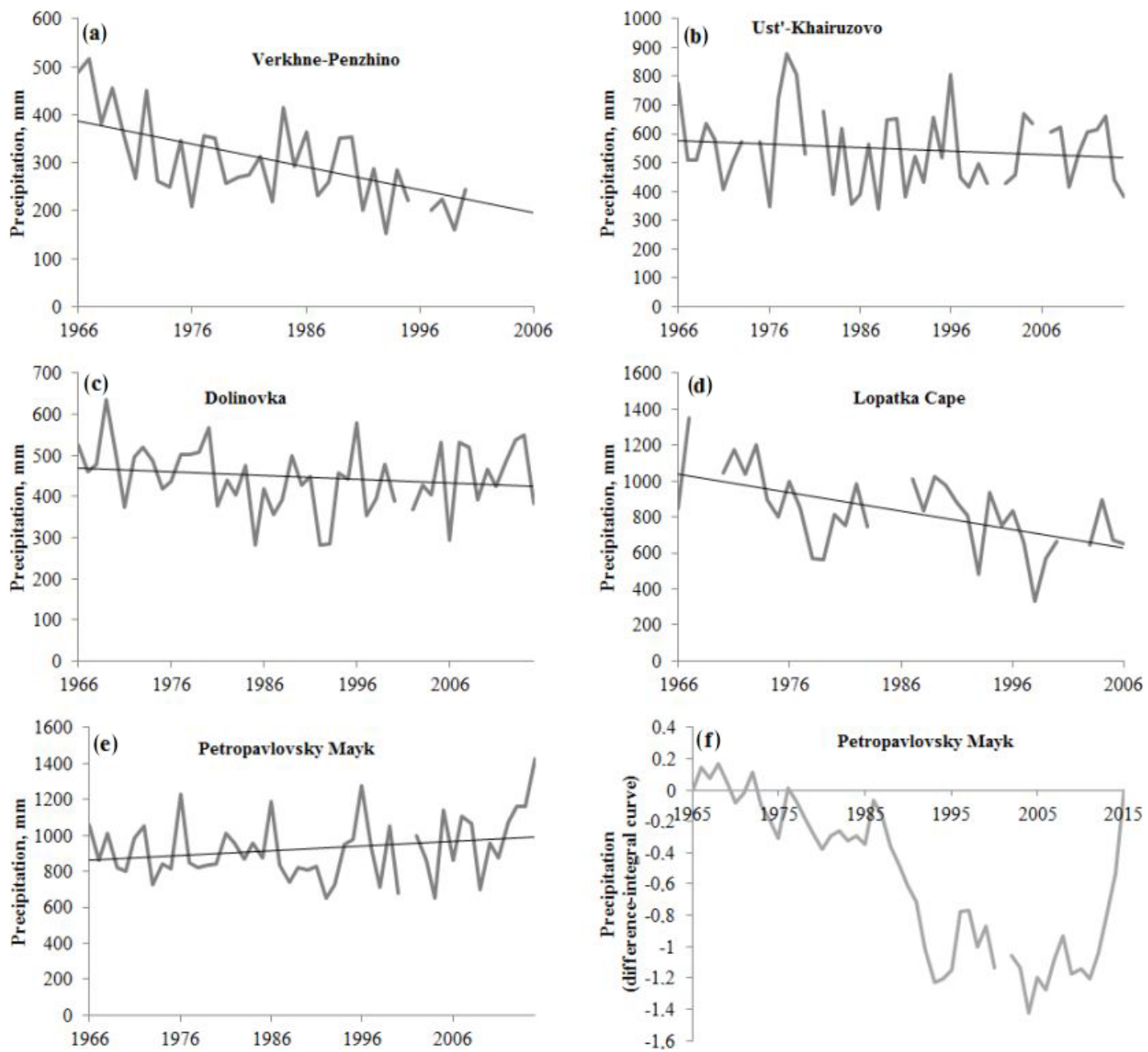

Figure 3. Trends in precipitation change in the northern (continental) part (Verkhne-Penzhino station, a), western coast (Ust'-Khairuzovo station, b), central part (Dolinovka station, c), the very south of the peninsula (Lopatka Cape station, d), and eastern coast (Petropavlovky Mayk station, e, f) in the Kamchatsky Krai.

Geographical position of the Kamchatsky Krai and orography of the region determine amount and distribution of the precipitation in the territory. The most intensive cyclonic activity is in the south; it subsides significantly to the north and decreases the mean annual amount of precipitation correspondingly. There are more precipitation on windward eastern flanks of mountains, while on leeward western flanks and protected river valleys. Analysis of precipitation data demonstrates variability of mean annual values from $300 \mathrm{~mm} \mathrm{yr}^{-1}$ in the north of the region to $1310 \mathrm{~mm} \mathrm{yr}^{-1}$ in the south-east of Kamchatka.

Variability of precipitation can influence on sediment yield directly (through intensity of sediment washout from the river basin territory) and indirectly (through variation of river water runoff). According to (Shkaberda, 2014) research the annual amount of precipitation varies in multiple-value way in Kamchatka. She mentioned decrease of precipitation was observed in the north, western and north-eastern coast, and in the Kamchatka River valley. Increase of them was observed in the eastern coast and in mountainous regions.

Our estimations demonstrate decrease of precipitation all over the Kamchatsky Krai territory but intensity of the process varies (Fig. 3a, b, c, d). The only one exception is Petropavlovsky Mayak station. In (Shkaberda, 2014) the increase of precipitation in that case is explained by positive anomaly in precipitation according to difference-integral curve (see Fig. 3e, f).

Changes in precipitation amount influence on rainfall erosive factor $R$ which has particular importance for controlling suspended sediment yield. Rrepresents the number of rainfall erosion index units, and characterizes the erosive potential of precipitation (Wischmeier et al., 1971). For the Kamchatsky Krai, the distribution of the rainfall factor was obtained by combining data from $R$-distribution maps (Larionov, 1993) with more recent precipitation data (since 2015). The intensity of erosion depends on rainfall erosive fac- 


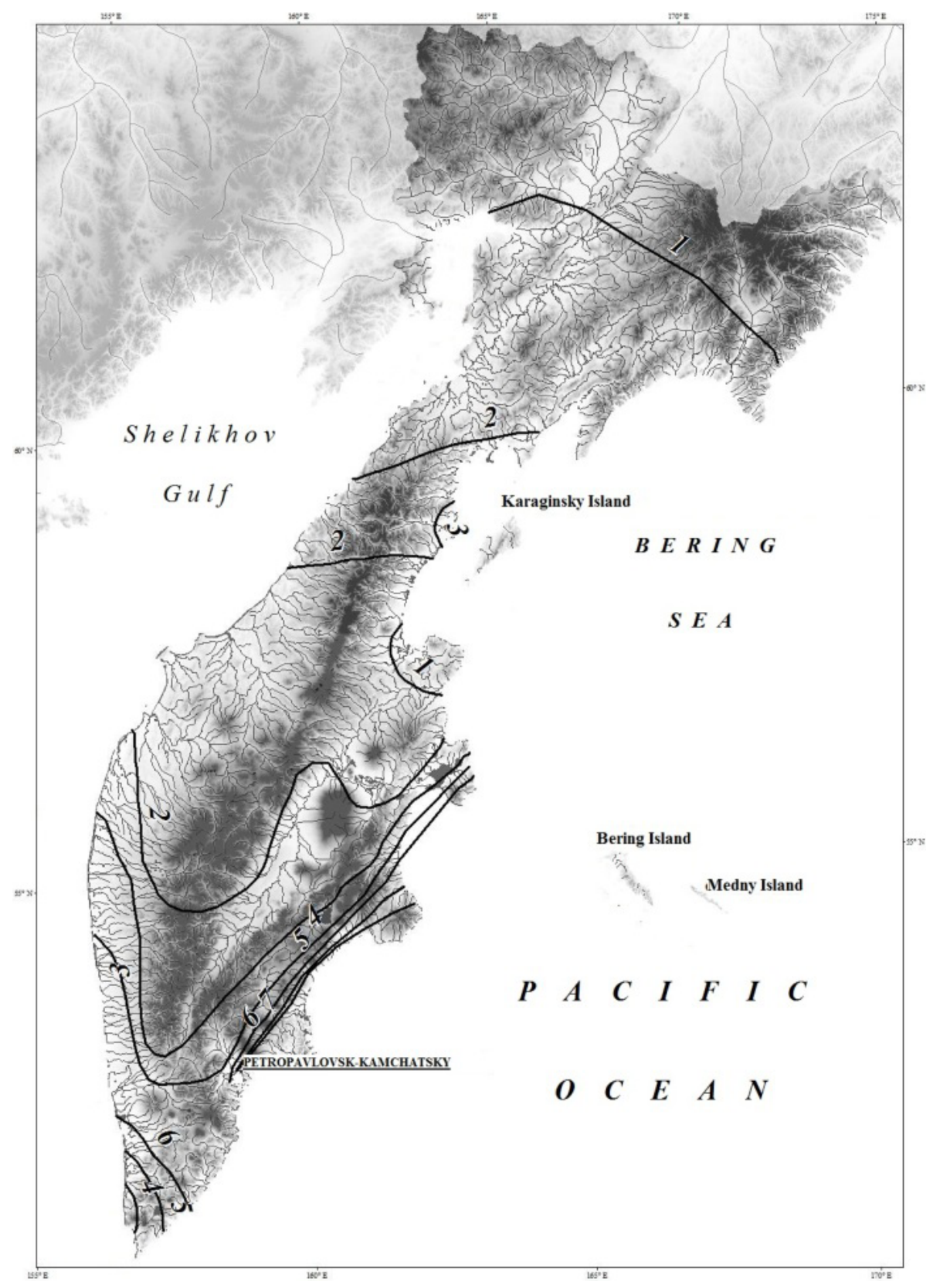

Figure 4. Rainfall erosive factor distribution in the Kamchatsky Krai territory.

tor considering the rainfall amount and intensity, shock action of rain drops and rock capacity to absorb water (Wischmeier and Smith, 1978). In the Kamchatsky Krai rainfall erosive factor varies from 0.1 in the very north of the region (Slautnoe settement) to 8.2 in the south-east (PetropavlovskKamchatsky). Maximum values of rainfall erosive index are observed in Vostochny volcanic, Vostochny seaside regions and Zapadnaya Kamchatka plain. The minimum values characterizes the northern part of the region (Kuksina and Alexeevsky, 2014) (Fig. 4). It was found there is a positive correlation between $R$-factor and annual precipitation amount for the Kamchatsky Krai territory (Kuksina and Alexeevsky, 2016). Comparison of $R$-factor for two periods (before and after 1974) demonstrates decrease of it in all regions of the Kamchatsky Krai. The most intensive decrease of $R$-factor is observed in the north of the Kamchatsky Krai (continental part) where the value differs almost two times for these periods ( $R$-factor decreased approximately in $45 \%$ ). Close results are observed in the very south of the peninsula $(R$-factor decreased approximately in $40 \%)$. Decrease of $R$-factor in the west coast doesn't exceed $28 \%$ (for Ust'-Kharuzova station it's $8 \%$ only). In the eastern coast decrease of $R$-factor 

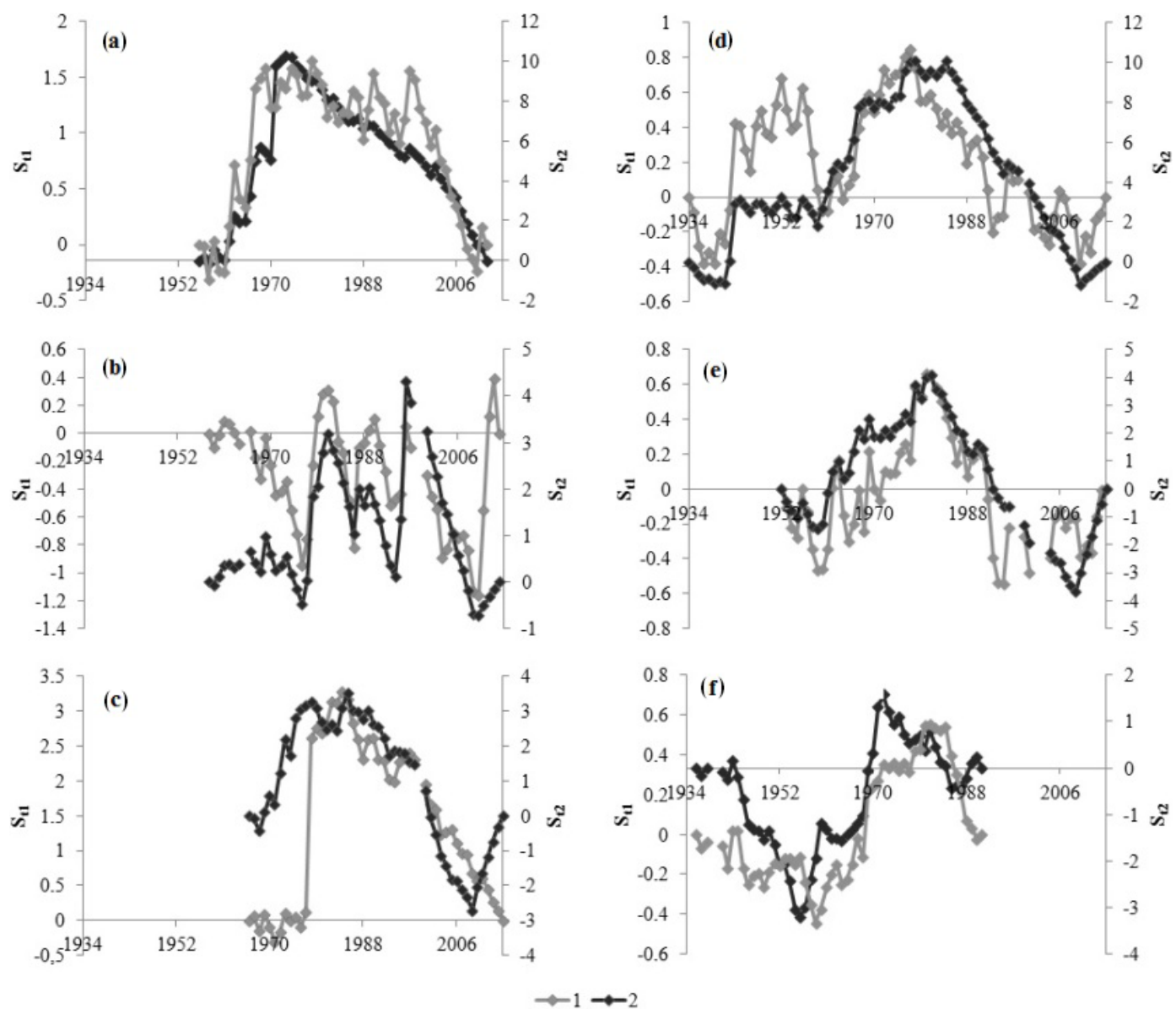

Figure 5. Trends in water discharge $\left(1, S_{\mathrm{t} 1}\right)$ and suspended sediment yield $\left(2, S_{\mathrm{t} 2}\right)$ variability in the Penzhina River (Kamenskoe gauge, a), the Khairyuzova River (Khairyuzovo gauge, b), the Udova River (Rus' gauge, c), the Avacha River (Elizovo gauge, d), the Kirganick River (Kirganick gauge, e), the Kamchatka River (Bol'shie Sheki gauge, f).

reaches $25 \%$ (except Petropavlovsky Mayak with the increase of $R$-factor for $4 \%)$. The great difference of $R$-factor variability is observed in the Kamchatka River basin. For some meteorological stations it almost hasn't changed (the difference is less than $1 \%$ ), while for other stations it reaches $28 \%$.

The main factors of the sediment yield formation and variability in the Kamchatsky Krai are precipitation (amount, intensity and frequency), relief characteristics, soil and vegetable cover, and volcanic processes (Kuksina and Alexeevsky, 2018). And while such factors as relief, soil and vegetation are relatively stable in the region (expect endogenous volcanic activity with its occasional revelation), precipitation characteristics varies greatly in space and time in the territory, so precipitation, its characteristics, i.e. $R$-factor, is the driving factor of sediment yield formation and variability. Exclusion are territories under strong volcanic impact where sediment yield and factors of its formation and variability (e.i. relief, soils and vegetation) can change dramatically after volcanic eruptions (Kuksina and Alexeevsky, 2017).

\section{Variability of suspended sediment yield}

Significant trends in suspended sediment yield variability were revealed on the basis of difference-integral curves analysis. These fluctuations were compared with changes in water runoff and meteorological characteristics. Analysis of difference-integral curves for river basins of various areas demonstrates these patterns in Kamchatka rivers appears to be independent of basin area.

Analysis of difference-integral curves for rivers in the north of the Kamchatsky Krai (continental part of the region) was implemented on the basis of data of 59 years duration for the Penzhina River (Kamenskoe gauge, basin area is $71600 \mathrm{~km}^{2}$ ). Duration of observations for other rivers in the area doesn't exceed 18 years, and the revelation of longterm trends is difficult for river runoff characteristics. The Penzhina River is characterized by two relatively long trends in suspended sediment yield trends. There was an increase in SSY between 1957 and 1974, with a subsequent decline between 1975 and 2012 (Fig. 5a). These trends are very well coincided with fluctuations of water runoff and precipitation 

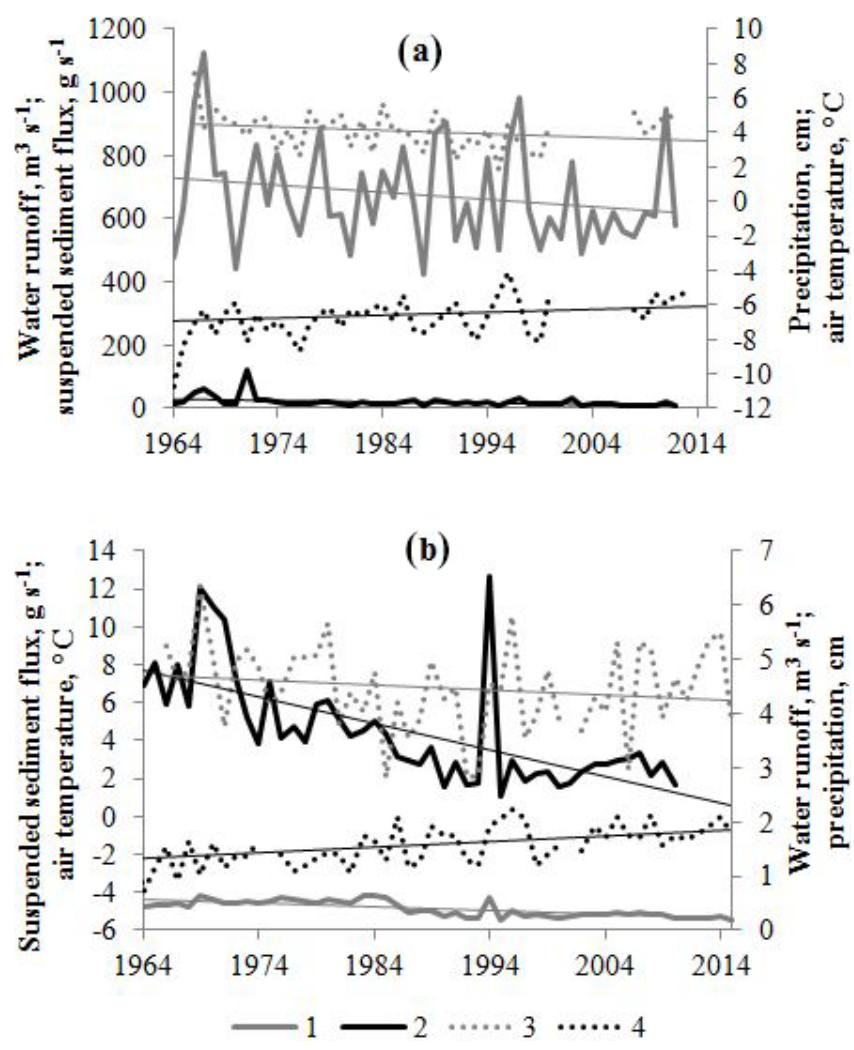

Figure 6. Correspondence of water runoff (1), suspended sediment yield (2), precipitation (3) and air temperature (4) variability in the Penzhina River (Kamenskoe, a) and the Dolinovka River (Dolinovka, b).

amount. There are three relatively long trends in water runoff variability; water runoff increased from 1957 to 1969, appeared close to be normal between 1970 and 1997, and declined from 1998 to 2010. These trends are very well timed with precipitation variability. Analysis of the data after 2010 revealed new increase in water runoff, and growth of precipitation at the same period. Reduction of water runoff in average reached $15 \%$, sediment yield $-41 \%$.

Rivers in the western part of the peninsula are characterized by synchronous variation in long-term trends of water runoff and SSY. The maximum duration of observations (57 years) is in the Khairuzova River basin (Khairuzovo gauge, basin area is $6680 \mathrm{~km}^{2}$ ). The trends display no longterm trends; water runoff and SSY increased from 1976 to 1981, appeared close to normal between 1982 and 1996, declined from 1997 to 2009, and increased again after 2010 (Fig. 5b). Variability of precipitation amount, water runoff and suspended sediment yield are synchronous (against the background of heightened annual precipitation variability).

Rivers in the south-western part of Kamchatka are characterized by less coincidence in water runoff and suspended sediment yield variations. River runoff increased till the late 1970 - early 1980 in the region, and then it started to de- crease, and water runoff continue to decrease nowadays, while suspended sediment yield started to increase in 2010 (Fig. 5c). Reduction of water runoff in average reached $25 \%$, sediment yield $-32 \%$.

Long-term trends in water runoff and suspended sediment yield are synchronous for rivers in the eastern part of the peninsula (with shift in start and end of phases with characteristic variation in river runoff). The longest observations are in the Avacha River basin (Elizovo gauge, basin area $4750 \mathrm{~km}^{2}$ ) with duration of 78 years. In the eastern part of the peninsula, water runoff and SSF increased synchronously between 1941 and 1977, and then subsequently declined (Fig. 5d) till 2009; in 2010 has started increase against the background of precipitation growth. Reduction of water runoff in average reached $6 \%$, sediment yield $-49 \%$

The maximum amount of gauges (21) with representative monitoring data on water runoff and suspended sediment yield with duration of observations from 37 to 78 years is in the central Kamchatka region. In this part of the peninsula two phases of water runoff and SSY fluctuations occurred; increased runoff was observed till the late 1970s, followed by a period of reduced runoff (till 2009); the tendency changed to increased runoff again in 2010 (Fig. 5e). Variability of precipitation amount, water runoff and suspended sediment yield are synchronous (against the background of heightened annual precipitation variability). Reduction of water runoff in average reached 2 , sediment yield $-21 \%$. This regularity is disturbed in rivers under impact of volcanic eruptions. For these rivers two phases of water runoff and SSF fluctuations occurred; reduced runoff was observed from the mid 1950s to the 1960s, followed by a period of increased runoff (Fig. 5f). Such response is mainly connected with the major eruption in Kamchatka in XX century of Bezymyanny volcano in March, 1956 (Gorshkov and Bogoyavleskaya, 1965). Rivers draining flanks of active volcanoes are characterized by quite synchronous fluctuations of water runoff and sediment yield.

Air temperature variability is in antiphase with water runoff and suspended sediment yield characteristics fluctuations (Fig. 6a, b).

\section{Conclusions}

On the basis of data on air temperature, precipitation, water runoff and suspended sediment yield analysis the main trends in sediment yield variability were revealed for the Kamchatsky Krai territory. Precipitation influences on sediment yield variability significantly through rainfall erosive factor (direct influence on sediment yield through sediment washout from river basins) and precipitation amount (indirect influence on sediment yield through water runoff), while variation of air temperature is in antiphase with water runoff and sediment yield characteristics. The decrease of precipitation is observed all over the Kamchatsky Krai territory (ex- 
pect one station in the eastern coast with positive anomaly of precipitation), and it's very well coincided with fluctuations of water runoff and sediment yield in the territory. Most part of the rivers in the region is characterized by two relatively long-term trends in water runoff and sediment yield fluctuations. Increase of these characteristics was observed till the late 1970 - early 1980 , and than decrease of them was registered till 2010. Analysis of the data after 2010 (till 2015) revealed new increasing trend in water runoff and sediment yield which is confirmed with precipitation variability. According to decrease of precipitation amount decrease of $R$ factor is observed in the Kamchatsky Krai (Kuksina and Alexeevsky, 2016). The value of this reduction varies from less than $1 \%$ (in some station in the Kamchatka River basin) to $45 \%$ (in the continental part of the region). Obviously decrease of $R$-factor leads to decrease of erosion rates and sediment yield consequently due to $R$-factor is driving force and the most changeable factor of sediment yield formation and variability in the Kamchatsky Krai. Exclusion is territories under strong impact of volcanic processes where volcanic eruptions can dramatically influence on sediment yield characteristics and factors of its formation.

Data availability. Underlying research data on air temperature and precipitation in available at http://meteo.ru/ (last access: 1 July 2019). Data on water discharge and suspended sediment yield is not opened for free access.

Author contributions. Author collected and processed data on air temperature, precipitation, water discharge and suspended sediment yield in Kamchatka and revealed main regularities in those characteristics variability in the region.

Competing interests. The authors declare that they have no conflict of interest.

Special issue statement. This article is part of the special issue "Land use and climate change impacts on erosion and sediment transport". It is a result of the ICCE Symposium 2018 - Climate Change Impacts on Sediment Dynamics: Measurement, Modelling and Management, Moscow, Russia, 27-31 August 2018.

Acknowledgements. I'm grateful to Nikolay I. Alexeevsky (deceased), my supervisor, with whom we started that research of Kamchatsky Krai rivers and sediments.

Financial support. This research has been supported by the Russian Scientific Foundation (project no. 17-77-10047).

\section{References}

Carrivick, J. L., Manville, V., Graettinger, A., and Cronin, S. J.: Coupled fluid-dynamicssediment transport modelling of a Crater Lake break-out lahar: Mt. Ruapehu, New Zealand, J. Hydrol., 388, 399-413, 2010.

Evstigneev, V. M.: River runoff and hydrological estimations, MSU Press, Moscow, Russia, 1990 (in Russian).

Gorshkov, G. S. and Bogoyavlenskaya, G. E.: Bezymyanny volcano and features of its last eruption in 1955-1963, Moscow, Russia, 1965 (in Russian).

Gran, K. B. and Montgomery, D. R.: Spatial and temporal patterns in fluvial recovery following volcanic eruptions: channel response to basin-wide sediment loading at Mount Pinatubo, Philippines, GSA Bulletin, 117, 195-211, 2005.

Groisman, P. Y., Knight, R. W., Easterling, D. R., Karl, T. R., Hegerl, G. C., and Razuvaev, V. N.: Trends in intense precipitation in the climate record, J. Clim., 18, 1326-1350, 2005.

Helsel, D. R. and Hirsch, R. M.: Statistical methods in water resources. Techniques of Water-Resources Investigations of the United States Geological Survey, Book 4, Hydrologic Analysis and Interpretation, chap. A3, 522 pp., 2002.

Huntington, T. G.: Evidence for intensification of the global water cycle: review and synthesis, J. Hydrol., 319, 83-95, 2006.

Korup, O.: Earth's portfolio of extreme sediment transport events, Earth Sci. Rev., 112, 115-125, 2012.

Kraevaya, T. S.: Short characteristic of mudflow regions in Kamchatka, KazNIGMI Proceedings, 33, 144-151, 1969 (in Russian).

Kuksina, L. V. and Alekseevski, N. I.: Space and Time Variations of the Runoff of Kamchatka Krai Rivers, Water Resour., 43, 438447, 2016.

Kuksina, L. V. and Alekseevski, N. I.: The transformation of the runoff of the suspended load in Kamchatkan rivers due to volcanism, J. Volcanol. Seismol., 11, 59-70, 2017.

Kuksina, L. V. and Alexeevsky, N. I.: Spatial and temporal variability of suspended sediment yield in the Kamchatka Krai, Russian Federation, IAHS-AISH P., 367, 304-311, 2014.

Kuksina, L. V. and Alexeevsky, N. I.: Suspended sediment yield transportation by rivers of the Kamchatsky Krai into the Pacific Ocean, the Sea of Okhotsk and the Bering Sea, International Journal of River Basin Management, 17, 37-47, https://doi.org/10.1080/15715124.2018.1446963, 2018.

Kuksina, L. V., Golosov, V. N., and Kuznetsova, Yu. S.: Cloudburst floods in mountains: state of knowledge, occurrence, factors of formation, Geogr. Nat. Resour., 38, 20-29, 2017.

Larionov, G.A.: Erosion and deflation of soils: major regularities and quantitative estimation, Moscow, Russia, 200 pp., 1993.

Lavigne, F. and Thouret, J. C.: Sediment transportation and deposition by rainfall triggered lahars at Merapi Volcano, Central Java, Indonesia, Geomorphology, 49, 45-69, 2002.

Leonov, A., Leonov, V., and Hobart, J.: Valley of Geysers, Kronotsky Reserve, Kamchatka: features seen by the 1991 GOSA Expedition and Changed by the 2007 Landslide, 2013 Cyclone and 2014 Landslide, The Newsletter of the Geyser Observation and Study Association (GOSA), 28, 5-26, 2014.

Major, J. J.: Posteruption suspended sediment transport at Mount St. Helens: decadal-scale relationships with landscape adjust- 
ments and river discharges, J. Geophys. Res., 109, F01002, https://doi.org/10.1029/2002JF000010, 2004.

Major, J. J. and Mark, L. E.: Peak flow responses to landscape disturbances caused by the cataclysmic 1980 eruption of Mount St. Helens, Washington, GSA Bulletin, 118, 938-958, 2006.

Major, J. J., Crisafulli, C. M., Frenzen, P., and Bishop, J.: After the disaster: The hydrogeomorphic, ecological, and biological responses to the 1980 eruption of Mount St. Helens, Washington, in: Volcanoes to Vineyards: Geologic Field Trips through the Dynamic Landscape of the Pacific Northwest: Geological Society of America Field Guide, O'Connor, edited by: O'Connor, J. E., Dorsey, R. J., and Madin, I. P., 15, 1-24, 2009.

Manh, N. V., Merz, B., and Apel, H.: Sedimentation monitoring including uncertainty analysis in complex floodplains: a case study in the Mekong Delta, Hydrol. Earth Syst. Sci., 17, 3039-3057, https://doi.org/10.5194/hess-17-3039-2013, 2013.
Mueller, E. N. and Pfister, A.: Increasing occurrence of highintensity rainstorm events relevant for the generation of soil erosion in a temperate lowland region in Central Europe, J. Hydrol., 411, 266-277, 2011.

Report on climate risks in the Russian Federation territory, SaintPetersburg, 106 pp., 2017 (in Russian).

Shkaberda, O. A. and Vasilevskaya, L. N.: Long-term changes of temperature and humidity regime in Kamchatka Peninsula, TINRO Proc., 178, 217-233, 2014 (in Russian).

Wischmeier, W., Johnson, C., and Cross, B.: A soil erodibility nomograph for farmland and construction sites, J. Soil Water Conserv., 26, 189-193, 1971.

Wischmeier, W. H. and Smith, D. D.: Predicting rainfall erosion losses: A guide to conservation planning, Agric, Handbook, 67 pp., 1978. 